\title{
Direct sowing of holm oak acorns: effects of acorn size and soil treatment
}

\author{
Francisco Bruno NAVARRo ${ }^{\text {** }}$, María Noelia JiMÉNEZ ${ }^{\text {a }}$, María Ángeles RIPOLL ${ }^{\text {, }}$ \\ Emilia FERNÁNDEZ-ONDOÑo ${ }^{\mathrm{b}}$, Eduardo GALLEGO ${ }^{\mathrm{a}}$, Estanislao DE SIMÓN ${ }^{\mathrm{a}}$

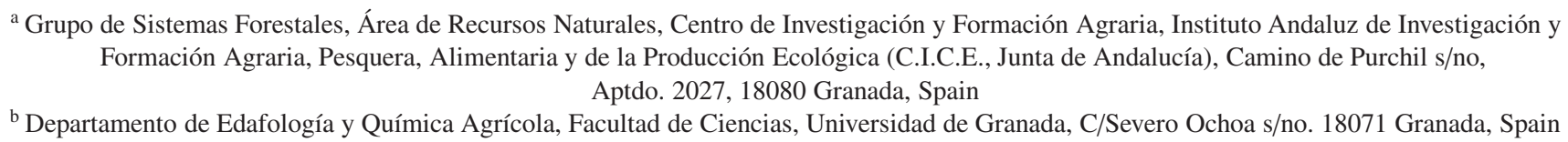

(Received 14 February 2006; accepted 27 June 2006)

\begin{abstract}
A nursery experiment under optimal controlled conditions and a parallel field trial under conditions of severe water stress were conducted to test the influence that acorn size and soil preparation (only in field) exert on the survival and development of this species. The soil preparation consisted of preparing seed beds with a backhoe. The size and weight of the acorn were the factors that most controlled the development of this species in the nursery, while in the field, under conditions of water stress, only acorn weight was related negatively to the root:shoot ratio. Water availability was also found to be a strongly limiting factor for plant development, when the results of the two experiments were compared. In the field, the prior soil preparation negatively affected survival $(65 \%)$ with respect to control $(95 \%)$, RCD and $\mathrm{R} / \mathrm{S}$ ratio. In conclusion, given the low precipitation during the study period and the low survival results reported by other researchers with the introduction of seedlings, even in higher-rainfall localities, sowing acorns directly in the field should be reconsidered as a viable technique for restoring holm oak forests, for forestation on agricultural lands, or the diversification of forest species on a large scale at low costs.
\end{abstract}

Quercus ilex subsp. ballota / acorn / soil treatment / abandoned agricultural land

Résumé - Semis directs des glands de chênes : effet de la grosseur des glands et du traitement du sol. Un essai en pépinière en conditions contrôlées optimales et un autre essai en plein champ en conditions de stress hydrique sévère pour le chêne ont été menés pour tester l'influence que la grosseur des glands et la préparation du sol (seulement au champ) exercent sur la survie et le développement de cette espèce. La préparation du sol a consisté en un poquet réalisé avec un retroexcavateur. La grosseur et le poids du gland ont été les facteurs qui ont provoqué le développement plus important de cette espèce en pépinière. Néanmoins, en plein champ, dans des conditions de stress hydrique seul le poids du gland a permis d'établir une corrélation négative avec le rapport racine/pousse. La disponibilité en eau a été un facteur extrêmement limitant pour le développement des plants, si on compare les résultats des deux expérimentations. Au champ, la préparation du terrain a influencé d'une manière négative la survie (65\%) par rapport au témoin $(90 \%)$, au diamètre des plants et au rapport racine/pousse. En conclusion, compte tenue des faibles pluies tombées pendant la période d'étude et des résultats de faible survie obtenus par d'autres auteurs avec l'introduction de semis, même dans des régions de pluviométrie plus abondante, le semis direct de glands au champ doit être repensé en tant que technique viable pour la restauration des forêts de chêne, le reboisement des terres agricoles et la diversification à grande échelle des espèces forestières et à moindre coût.

Quercus ilex subsp. ballota / gland / traitement du sol / terre agricole abandonnée

\section{INTRODUCTION}

The holm oak (Quercus ilex L. subsp. ballota (Desf.) Samp.) is one of the most representative species in the forest communities of the Mediterranean basin [35], especially on the Iberian Peninsula, where it forms part of the vegetation (existing as well as potential) in extensive areas $[18,39]$. The use of this evergreen sclerophilous tree in reforestation programs on abandoned agricultural lands promoted by the Common Agricultural Policy (CAP) has strongly increased in the last 12 years, in contrast to the Pinus species, which were widely used in the past [47]. Only in Andalusia (Spain), more

\footnotetext{
*Corresponding author: francisco.bruno.ext@ juntadeandalucia.es
}

than 75000 ha were reforested from 1993 to 1999, implying the introduction of millions of new seedlings.

Nevertheless, forestation with the holm oak presents survival difficulties and low growth rates in comparison to other Mediterranean tree or shrub species [1,2], and more so the stronger the stress factors during the first developmental stage in the field. It is widely known that the first Mediterranean summer after planting is the most critical period for the survival of this species due to high temperatures, excessive solar radiation, and low water availability $[21,33,45]$. These difficulties accentuate within the limits of the distribution of this species, whether for climatic dryness (semiarid habitats $\mathrm{Pp}<350 \mathrm{~mm}$ ) or for the lack of soil, poor water-retention capacity of the soil, or unfavourable exposures. 
Some authors propose that the poor performance of forestation stands of $Q$. ilex subsp. ballota could be attributed to the low quality of seedlings used, as the cultivation regime in the nursery can strongly determine functional characteristics and response of the seedling in the field [47]. However, the high mortality rates of reforested seedlings in localities where there is even a vigorous natural regeneration suggest that not only the type of holm oak seedling commonly used in forestation but also the technique of introducing this species into the field should be reviewed.

Therefore, a large portion of recent forest research in the Mediterranean basin has focussed on finding alternative methods of planting species of the genus Quercus, especially the holm oak ( $Q$. ilex subsp. ballota) and the cork oak ( $Q$. suber $)$. These studies have centred fundamentally on enhancing the quality of nursery seedlings $[11,47]$, improving planting techniques $[2,37,44]$, and finding effective post-planting treatments $[17,26,34,41,42]$.

On the other hand, little attention has been given to forestation by sowing acorns directly in the field. In Mediterranean environments, one of the variables that can increase the probability of survival is the access to soil water during summer, which can be achieved with a stronger root system and/or a deeper one [46]. Therefore, the growth rate of the root during the first months of life (winter-spring) can be crucial to the survival of the seedling over the dry season [20]. A deep tap root is one of the main strategies of the holm oak seedling for survival during the early establishment phase, making direct sowing of the acorn an attractive alternative to planting seedlings, with the added advantage of being a low-cost method. In this sense, some authors warn of the possible negative effects caused by the deformation of the roots of containergrown holm oak [15].

Some direct-sowing trials of acorns have shown very uneven survival results with respect to the planting of seedlings $[5,27,31,37]$, perhaps due to the origin and sizes of the acorns used, the ways of collecting and storing the acorns, pre-germination treatments, conditions of the sowing, climatology of the year of planting, the interference of seed predators, etc. Few works clarify these issues in sowing experiments. Along these lines, Castro et al. [7] note that the effect of seed size upon seedling performance can be easily confused with the effect exerted by the genetic determination of the maternal plant when the experiments are performed with mixed groups of genotypes. Therefore, new experiments controlling all these variables need to be performed.

The present work examines in detail some factors that can affect the rooting of holm oak seedlings after direct sowing of the acorns, such as acorn size and pre-sowing soil preparation.

\section{MATERIALS AND METHODS}

In autumn 2002 (early November), acorns of different sizes but from the same tree were collected in the north of the province of Granada (Guadix plateau, S Spain). Healthy acorns without apparent defects were numbered, measured for length and diameter $(\mathrm{mm})$, and weighed $(\mathrm{g})$. Then they were stratified in wet sand at $4{ }^{\circ} \mathrm{C}$ to
Table I. Biometric characteristics of the acorns used in the field experiment $(n=40)$.

\begin{tabular}{lcccc}
\hline & Mean & SE & Min. & Max. \\
\hline Diameter $(\mathrm{mm})$ & 17.66 & 0.16 & 15.29 & 20.36 \\
Length $(\mathrm{mm})$ & 42.25 & 0.27 & 37.62 & 45.75 \\
Weight $(\mathrm{g})$ & 8.02 & 0.16 & 5.41 & 9.93 \\
\hline
\end{tabular}

stimulate germination. A total of 20 acorns were used in the nursery experiment, and 40 in the field experiment.

\subsection{Nursery experiment}

The 20 acorns selected were classified into two significantly distinct groups according to size (Small acorns: diameter $(\mathrm{mm})=$ $16.33 \pm 0.31 \mathrm{a}$, length $(\mathrm{mm})=38.80 \pm 1.03 \mathrm{a}$, weight $(\mathrm{g})=6.24 \pm 0.37 \mathrm{a}$; Large acorns: diameter $=22.20 \pm 0.33 \mathrm{~b}$, length $=43.57 \pm 1.10 \mathrm{~b}$, weight $=12.58 \pm 0.39 \mathrm{~b}$; different letters indicate different significances at 95\% confidence level [one-way ANOVA, Tukey test]) and sown (pre-germinated) at $5 \mathrm{~cm}$ deep on 18 December 2002 in PVC cylinders (180 cm tall, $25 \mathrm{~cm}$ in diameter) filled with nursery substrate consisting of $2 / 3$ peat and $1 / 3$ perlite. These tubes were situated in the open air at the Centre for Agricultural Research and Training of Granada (S Spain), where, apart from rainfall, the tubes received periodic watering to provide the seedling constant available moisture, which was controlled by a Watermark ${ }^{\circledR}$ tensiometer situated at $90 \mathrm{~cm}$ in depth (middle of the tube).

The seedlings were measured for height $(\mathrm{cm})$, diameter at the root collar (RCD, mm), and the number of leaves in July and October 2003 as well as in February and November of 2004.

This type of container was used to analyse the root system of the plants at the end of the study period [(tap-root length, biomass of secondary roots (>2 $\mathrm{mm}$ diameter, $\mathrm{GB}$ ), biomass of the hair roots $(<2 \mathrm{~mm}$ diameter, FB), and biomass of the total root system (RB)]. Also, the biomass of the stems (SB), leaves (LB), and total-shoot biomass $(\mathrm{AB})$ was measured, as well as the root:shoot ratio $(\mathrm{R}: \mathrm{S})$, and total weight $(\mathrm{TB}=\mathrm{AB}+\mathrm{RB})$. This destructive analysis was performed in November 2004, two years after the controlled cultivation in the nursery.

\subsection{Field experiment}

Of the 40 acorns selected for the field trial (Tab. I), half were taken at random and sown at $5 \mathrm{~cm}$ in depth without prior soil preparation. The other half were sown at the same depth but in beds prepared by a backhoe with a small blade $(70 \times 35 \times 50 \mathrm{~cm})$, in a complete, randomized block. The acorns were sown in the open on 19 December 2002, on $5 \times 5 \mathrm{~m}$ centres, one day after the nursery sowing. The acorns were also sown pre-germinated and each was protected from seed predators with a cylinder of wire mesh.

With respect to sowing with vs. without prior soil preparation, no significant differences (one-way ANOVA) were found in the initial characteristics of the acorns (length: $F_{(1,39)}=1.29, P=0.9261$; diameter: $F_{(1,39)}=1.10, P=0.3046$; weight: $F_{(1,39)}=0.44, P=$ 0.5109). 
This experiment was made in the Altiplano del Conejo of Guadix in the province of Granada (S Spain) at $1000 \mathrm{~m}$ a.s.l. The mean annual precipitation is $304 \mathrm{~mm}$, with marked irregularity $(\mathrm{Pp}(\mathrm{mm})$ : October 2002-2003 = 302.1, October 2003-2004 = 363.4, October 2004-2005 = 167.7) and extreme temperatures, summer reaching $43.4{ }^{\circ} \mathrm{C}$ (August 2003) and winter $-17{ }^{\circ} \mathrm{C}$ (January 2003). The bioclimatic level of this zone is semiarid mesomediterranean [36]. The soil is a petric calcisol [12] with a $\mathrm{pH}$ of 7.2 to 8.5 , of loamy-sandy clay. The land, homogeneous abandoned agricultural land with scattered holm oaks, was traditionally dedicated to cereal until the activity stopped in 1993 when the government bought the lands.

These seedlings were monitored for survival, height, and RCD in October 2003, February and July of 2004, and July of 2005. In July 2005, 16 saplings were uprooted, eight per treatment (control, soil treatment) to be measured for length of the tap root, $\mathrm{LB}, \mathrm{SB}, \mathrm{FB}, \mathrm{GB}$, AB, RB, R:S and TB. Also, soil samples were taken at 0-20, 20-30 and $30-40 \mathrm{~cm}$ in depth, both in unprepared soil as well as in the beds prepared by the backhoe. Analyses were made of the gravel content as well as $\mathrm{CaCO}_{3}, \mathrm{~N}, \mathrm{P}, \mathrm{K}, \mathrm{Na}, \mathrm{Mg}, \mathrm{Cu}, \mathrm{Mn}, \mathrm{Fe}$ and $\mathrm{Zn}$ concentrations. The following were also determined: total $\mathrm{N}$, by Kjeldahl method; exchangeable cations ( $\mathrm{Ca}, \mathrm{Mg}, \mathrm{K}, \mathrm{Cu}, \mathrm{Mn}, \mathrm{Fe}$ and $\mathrm{Zn}$ ) by extraction with $1 \mathrm{~N}$ ammonium acetate ( $\mathrm{pH} 7.0)$ [8]; available $\mathrm{P}$, by the classical Olsen method [28], and the $\mathrm{CaCO}_{3}$ equivalent, by a manometric method [48].

\subsection{Data analyses}

The data on height, RCD, and number of leaves in the nursery experiment were analysed separately for each sampling period, by a one-way ANOVA (acorn size factor). Similarly, the height and RCD data from the field were analysed for the factor "soil treatment".

The length of the tap root, $\mathrm{LB}, \mathrm{SB}, \mathrm{FB}, \mathrm{GB}, \mathrm{AB}, \mathrm{RB}, \mathrm{R}: \mathrm{S}$ and $\mathrm{TB}$, measured only at the end of the study period, both in the nursery as well as in the field experiment, were analysed also by a oneway ANOVA. The Tukey HSD test of all-pairwaise comparisons was run in all cases. Normality was checked by the Shappiro-Wilk test, and homogeneity by the Bartlett test. In the case of violation of variance equality, the nonparametric test of Kruskal-Wallis was used. The Pearson correlation was used to analyse the relationship between the initial characteristics of the acorns and the characteristics of the resulting plants. Field survival of seedlings was analysed by the Kaplan and Meier logrank test.

All statistical analyses were performed using the STATISTIX 8 (Analytical Software, Tallahassee, USA), except for survival, which was analysed with STATGRAPHICS Plus 4.0 (Manugistics, Rockville, USA).

\section{RESULTS}

\subsection{Nursery experiment}

In the nursery, acorn size significantly influenced the variables measured. The larger acorns produced taller plants with a greater number of leaves, and greater RCD from the first sampling to the end of the study period (Fig. 1). Similarly, after the final destructive analysis, the larger acorn lot gave rise to higher values for $\mathrm{AB}\left(F_{(1,19)}=36.9, P=0.0000\right), \mathrm{RB}$ $\left(F_{(1,19)}=24.0, P=0.0002\right), \mathrm{GB}\left(F_{(1,19)}=24.7, P=0.0002\right)$,
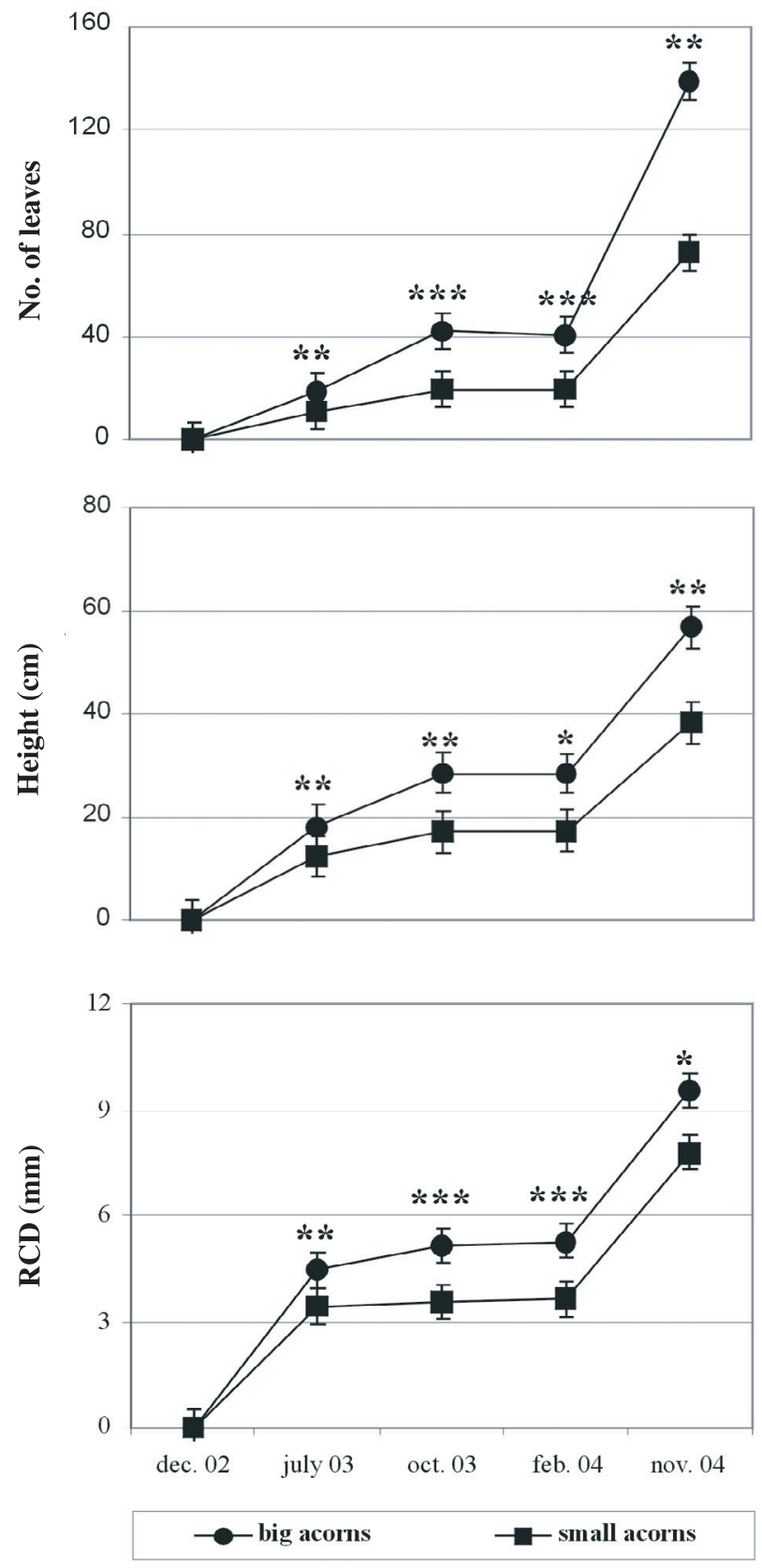

Figure 1. Evolution of height, RCD, and number of leaves of the holm oak nursery-cultivated seedlings in relation to the size of the acorn. * $0.05>P>0.01, * * 0.01>P>0.001$, *** $P<0.001$ (Tukey HSD all-pairwaise comparisons test).

$\mathrm{SB}\left(F_{(1,19)}=32.9, P=0.0000\right), \mathrm{LB}\left(F_{(1,19)}=28.8, P=\right.$ $0.0001)$ and TB $\left(F_{(1,19)}=32.5, P=0.0000\right)$. However, no significant differences were found with respect to FB, R:S ratio, or tap-root length, which reached a mean of $1.46 \pm 0.10 \mathrm{~m}$ in depth. A significant positive correlation was established between acorn size and most of the morphological variables of the plants after 24 months of growth (Tab. II). 
Table II. Results of the Pearson correlation analysis of the biometric characteristics of the nursery-sown acorns and the characteristics of the resulting plants after two years of cultivation $(n=20), r=$ Pearson correlation coefficient, $P=P$-value, $\mathrm{AB}=$ shoot biomass, $\mathrm{RB}=$ total root biomass, $\mathrm{GB}=$ secondary-root biomass $(>2 \mathrm{~mm}), \mathrm{SB}=$ stem biomass, $\mathrm{LB}=$ leaf biomass, $\mathrm{TB}=$ Total biomass; $* 0.05>P>0.01$, ** $0.01>P>0.001$, *** $P<0.001$.

\begin{tabular}{|c|c|c|c|c|c|c|c|c|c|}
\hline & & No. leaves & $\mathrm{AB}(\mathrm{g})$ & $\mathrm{RB}(\mathrm{g})$ & Height (mm) & GB $(g)$ & $\mathrm{SB}(\mathrm{g})$ & TB $(g)$ & LB $(g)$ \\
\hline \multirow[t]{2}{*}{ Acorn diameter (mm) } & $r$ & 0.5420 & 0.7181 & 0.7248 & 0.6459 & 0.7246 & 0.6917 & 0.7378 & 0.7043 \\
\hline & $P$ & $0.0246^{*}$ & $0.0012 * *$ & $0.0010 * *$ & $0.0051 * *$ & $0.0010 * *$ & $0.0021 * *$ & $0.0007 * * *$ & $0.0016 * *$ \\
\hline \multirow[t]{2}{*}{ Acorn length (mm) } & $r$ & 0.5612 & 0.7189 & 0.7115 & 0.6176 & 0.7069 & 0.7073 & 0.7303 & 0.6908 \\
\hline & $P$ & $0.0191 *$ & $0.001 * *$ & $0.0014 * *$ & $0.0083 * *$ & $0.0015 * *$ & $0.0015 * *$ & $0.0009 * * *$ & $0.0021 * *$ \\
\hline \multirow[t]{2}{*}{ Acorn weight (g) } & $r$ & 0.5989 & 0.7827 & 0.7928 & 0.7057 & 0.7903 & 0.7641 & 0.8058 & 0.7579 \\
\hline & $\mathrm{P}$ & $0.0111^{*}$ & $0.002 * *$ & $0.0001^{* * *}$ & $0.0016^{* *}$ & $0.0002 * * *$ & $0.0004 * * *$ & $0.0001 * * *$ & $0.0004 * * *$ \\
\hline
\end{tabular}

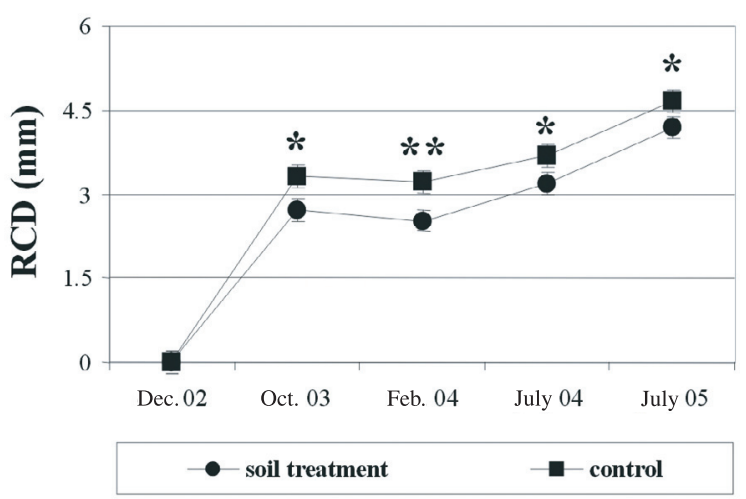

Figure 2. Evolution of the RCD of the holm oaks sown in the field in relation to the prior soil treatment made. $* 0.05>P>0.01, * * 0.01>$ $P>0.001, * * * P<0.001$ (Tukey HSD all-pairwaise comparisons test).

\subsection{Field experiment}

Of the 40 pre-germinated acorns sown at the Altiplano del Conejo in December 2002, 32 survived to July 2005 (80\%). Survival, with respect to control (95\%), was lower for the acorns sown with prior soil preparation $\left(65 \%, \chi^{2}=5.60\right.$, $P=0.017)$. It was also found that seedling survival was independent of acorn size and weight (Kruskal-Wallis test, $P>0.05)$.

In relation to seedling characteristics, only RCD and R/S ratio were significantly affected by the factor analysed. Soil preparation did not encourage growth of the RCD with respect to control from the outset of the study (Fig. 2), and the plants with prior soil preparation invested less in root biomass in relation to aboveground biomass than did control plants (Fig. 3). No significant correlation was found between the biometric parameters of the acorns and the morphological attributes of the resulting seedlings, except for R:S, which correlated negatively with acorn weight (Fig. 4).

The soil preparation homogenized the characteristics of the pedological profile, as can be appreciated in Table III. The $\mathrm{CaCO}_{3}$ content, which in the unaltered soil increased in depth,

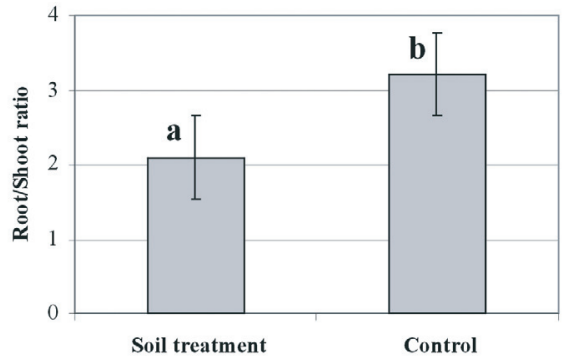

Figure 3. Root:Shoot allocation in relation to the prior soil treatment made. Different letters indicate the significant differences at $95 \%$ confidence level.

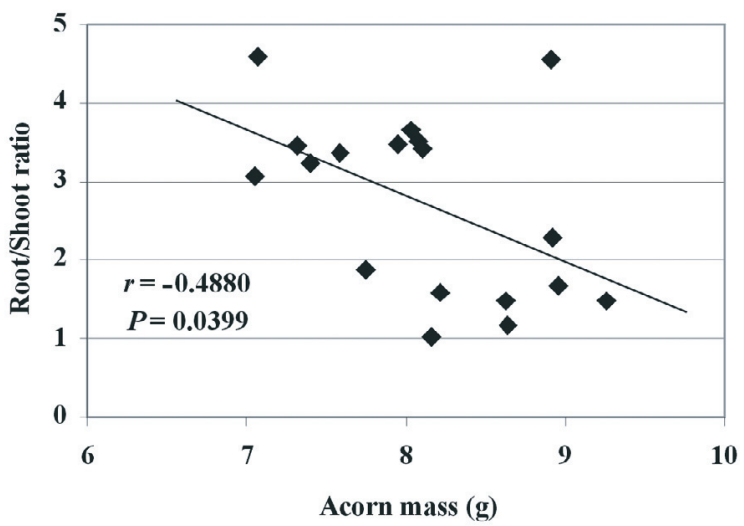

Figure 4. Root:Shoot allocation in relation to the weight of the acorns sown at the Altiplano del Conejo 32 months before. $r=$ Pearson correlation coefficient, $P=P$-value.

increasing on the surface of the prepared soil, the trend being the opposite with $\mathrm{P}$ and $\mathrm{K}$.

\subsection{Comparing nursery and field plants}

Although the nursery plants were harvested after 24 months of growing and the plants cultivated in the field were harvested after 32 months, the development of the size and weight 
Table III. Characteristics of the pedological profile of the untreated soil (control) and in the planting beds prepared with the backhoe (soil treatment).

\begin{tabular}{lcccccccccccccc}
\hline & Depth & gravels & $\mathrm{N}$ & $\mathrm{P}$ & $\mathrm{CaCO}_{3}$ & $\mathrm{Na}$ & $\mathrm{K}$ & $\mathrm{Mg}$ & $\mathrm{Cu}$ & $\mathrm{Mn}$ & $\mathrm{Fe}$ & $\mathrm{Zn}$ \\
\hline Treatment & $\mathrm{cm}$ & $\%$ & $\%$ & $\mu \mathrm{g} \cdot \mathrm{g}^{-1}$ & $\%$ & & $\mathrm{Cmol}_{c} \mathrm{~kg}^{-1}$ & & & $\mu \mathrm{g} \cdot \mathrm{g}^{-1}$ & \\
\hline Control & $0-20$ & 36.8 & 0.12 & 17.64 & 18.8 & 0.10 & 0.27 & 0.52 & nd & 0.53 & 0.07 & nd \\
& $20-30$ & 46.4 & 0.14 & 12.24 & 36.5 & 0.10 & 0.12 & 0.51 & nd & 0.17 & 0.14 & nd \\
& $30-40$ & 55.7 & 0.13 & 9.91 & 49.2 & 0.10 & 0.12 & 0.51 & nd & 0.20 & 0.12 & nd \\
\hline Soil treatment & $0-20$ & 50.0 & 0.10 & 9.50 & 46.1 & 0.08 & 0.15 & 0.53 & nd & 0.26 & 0.06 & nd \\
& $20-30$ & 40.0 & 0.11 & 12.65 & 41.9 & 0.08 & 0.18 & 0.53 & nd & 0.35 & 0.08 & nd \\
& $30-40$ & 52.5 & 0.10 & 14.65 & 38.8 & 0.10 & 0.15 & 0.53 & nd & 0.31 & 0.11 & nd \\
\hline
\end{tabular}
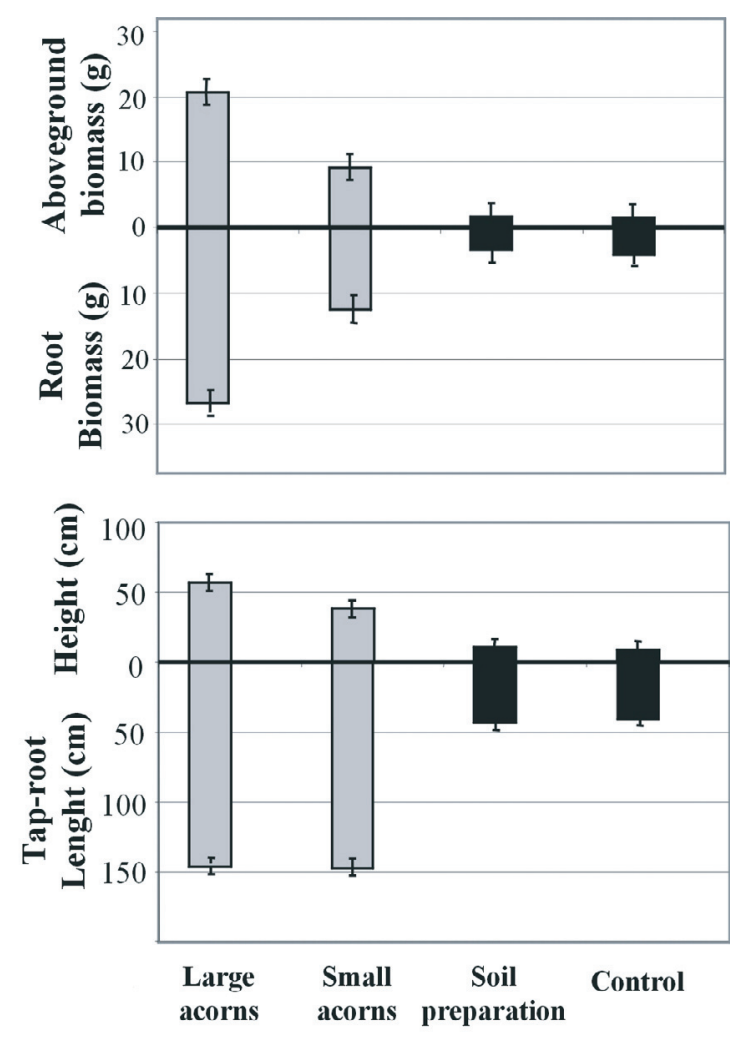

Figure 5. Comparative graph for development in mean size and weight of the nursery-sown plants (grey) harvested at 24 months, and those cultivated in the field (black) harvested at 32 months.

of the nursery-grown plants was far greater (Fig. 5). Similarly, the nursery plants had a more balanced $\mathrm{R}: \mathrm{S}$ ratio (small acorns $=1.30 \pm 0.08 \mathrm{a}$; large acorns $=1.31 \pm 0.09 \mathrm{a}$ ) than did those grown in the field (control $=3.22 \pm 0.32 \mathrm{a}$; prior soil preparation $=2.09 \pm 0.36 \mathrm{~b}$ ).

\section{DISCUSSION}

Under optimal water conditions in the nursery, the larger or heavier acorns produced significantly more vigorous seedlings, a result widely supported, not only in the genus Quercus $[16,25,30]$. Furthermore, it is established (for an exception, see [14]) that large seeds result in higher seedling survival $[3,10,20]$.

However, in the field experiment at the Altiplano del Conejo, under water-stress conditions, there was far less plant development (Fig. 5) and no relationship was found between acorn size or weight and survival or morphological characteristics of the plants over 32 months of development. This coincides with the results of Marañón et al. [23] that plant weight (after 50 days of growth) was independent of initial weight of the acorn for three Quercus species (see $[22,46])$. In this sense, some authors $[6,24,38]$ indicate that this positive relationship between seed weight and seedling growth may be restricted only to the first weeks or months after emergence, disappearing later during seedling development.

Only acorn weight negatively correlated with the root:shoot ratio (Fig. 4), this occurring only in the field experiment. This contrasts with the results reported by Leiva and FernándezAlés [19] and Lloret et al. [20]. On the other hand, it coincides with the findings of Valdecantos et al. [40,42] and VillarSalvador et al. [47], who found greater increases in shoot biomass, in $Q$. ilex seedlings which were fertilized or were grown in soil amended with organic matter, without detriment to root weight.

In contrast to the results reported by Nicolás et al. [27] with respect to sowing and planting of $Q$. ilex, as well as by Querejeta et al. [32] and Bocio et al. [2] regarding the planting of $Q$. ilex and Pinus halepensis Mill., soil preparation with a backhoe did not favour growth or survival of the holm oak with respect to those sown without preparation, but rather the contrary; this fact may have been due to some change in the soil properties caused by the soil preparation, such as increased $\mathrm{CaCO}_{3}$ content in the uppermost horizon coming from a deeper petrocalcic horizon (Tab. III). It has been confirmed that high $\mathrm{CaCO}_{3}$ concentrations in the soil solution can affect the germination and growth of seedlings, because they interfere in $\mathrm{P}$ and $\mathrm{K}$ assimilation [29,43]. In this sense, further research is needed.

Although $Q$. ilex is considered a shade-tolerant species in which the recruitment capacity falters when exposed to full sun $[4,33]$ or at high temperatures [49], if sowing is well planned (selected acorns, pre-germination treatments, protection against herbivores, mycorrhyzation, etc.), the survival can 
reach very high levels. In the present study, the mean survival in the field was $80 \%$ (95\% in control plants). Given the low precipitation during the study period and the low results reported by other researchers with the introduction of seedlings, even in higher-rainfall localities $[9,11,13,34]$, direct sowing of acorns in the field should be reconsidered as a technique for the restoration of holm oak forests, forestation of agricultural lands, or the diversification of forest spaces on a large scale at low cost.

Acknowledgements: This work was made possible by a predoctoral grant financed by the Instituto Nacional de Investigación Agraria (INIA) and a research grant financed by the system INIA-CCAA (Spain). We are grateful to David Nesbitt for the linguistic review of the English manuscript.

\section{REFERENCES}

[1] Baeza M.J., Pastor A., Martín J., Ibánez M., Mortalidad postimplantación en repoblaciones de Pinus halepensis, Quercus ilex, Ceratonia siliqua y Tetraclinis articulata en la provincia de Alicante, Studia Oecol. 8 (1991) 139-146.

[2] Bocio I., Navarro F.B., Ripoll M.A., Jiménez M.N., De Simón E., Holm oak (Quercus rotundifolia Lam.) and Aleppo pine (Pinus halepensis Mill.) response to different soil preparation techniques applied to forestation in abandoned farmland, Ann. For. Sci. 61 (2004) 171-178.

[3] Bonfil C., The effects of seed size, cotyledon reserves, and herbivory on seedling survival and growth in Quercus rugosa and Quercus laurina (Fagacee), Am. J. Bot. 85 (1998) 79-87.

[4] Broncano M.J., Riba M., Retana J., Seed germination and seedling performance of two Mediterranean tree species, holm oak (Quercus ilex L.) and Aleppo pine (Pinus halepensis Mill.): a multifactor experimental approach, Plant Ecol. 138 (1998) 17-26.

[5] Carreras C., Sánchez J., Reche P., Herrero D., Navarro A., Navío J.J., Primeros resultados de una repoblación mediante siembra con protectores en Vélez-Rubio (Almería), Cuad. Soc. Esp. Cien. For. 4 (1997) 135-139.

[6] Castro J., Seed mass versus seedling performance in Scots pine: a maternally dependent trait, New Phytol. 144 (1999) 153-161.

[7] Castro J., Hódar J.A., Gómez J.M., Seed size, in: Basra A. (Ed.), Handbook of seed science and technology, Haworth's Food Products Press, New York, 2006, 796 p.

[8] Chapman H.D., Cation-exchange capacity, in: Blank C.A., Evans D.D., White J.L., Ensminger L.E., Clark F.E. (Eds.), Methods of soil analysis, Vol. II, American Society of Agronomy, Madison, Wisconsin, 1965, pp. 891-901.

[9] Cortina J., Bellot J., Vilagrosa A., Caturla R.N., Maestre F.T., Rubio E., Ortíz De Uurbina J.M., Bonet A., Restauración en semiárido, in: Vallejo V.R. (Ed.), Avances en el estudio de la gestión del monte Mediterráneo, Fundación CEAM, Valencia, España, 2004, pp. 345406.

[10] Dalling J.W., Hubbell S.P., Seed size, growth rate and gap microsite conditions as determinants of recruitment success for pioneer species, J. Ecol. 90 (2002) 557-568.

[11] Del Campo A.D., Navarro R., Stoktypes quality of holm oak (Quercus ilex L. subsp. ballota (Desf.) Samp.) seedlings from different nurseries. Evaluation of field performance, Cuad. Soc. Esp. Cien. For. 17 (2004) 35-42.

[12] FAO-ISRIC, Base referencial mundial del recurso del suelo, FAO, Roma, 1998, 91 p.
[13] Fuentes D., Valdecantos A., Vallejo V.R., Planting Pinus halepensis Mill. and Quercus ilex L. subsp. ballota (Desf.) Samp. seedlings in dry Mediteranean environments with a water harvesting technique, Cuad. Soc. Esp. Cien. For. 17 (2004) 157-161.

[14] Gómez J.M., Bigger is not always better: Conflicting selective pressures on seed size in Quercus ilex, Evolution 58 (2004) 71-80.

[15] Gómez V., Ocaña L., Las marras causadas por defectos en las operaciones de reforestación, Cuad. Soc. Esp. Cien. For. 4 (1997) 35-42.

[16] Jarvis P.G., The effects of acorn size and provenance on the growth of seedlings of sessile oaks, Q. J. For. 57 (1963) 11-19.

[17] Jiménez M.N., Ripoll M.A., Navarro F.B., Bocio I., De Simón E., Modification of the edaphic microclimate produced by irrigation in afforestation of semiarid areas, Invest. Agrar. Sist. Recur. For. Fuera de serie (2004) 142-151.

[18] Jiménez-Sancho M.P., Díaz P., Iglesias S., De Tuero M., Gil L., Las regiones de procedencia de Quercus ilex L. en España, ICONA, Madrid, España, 1996.

[19] Leiva M.J., Fernández-Alés R., Variability in seedling water status during drought within a Quercus ilex subsp. ballota population, and its relation to seedling morphology, For. Ecol. Manage. 111 (1998) $147-156$.

[20] Lloret F., Casanovas C., Peñuelas J., Seedling survival of Mediterranean shrubland species in relation to root:shoot ratio, seed size and water and nitrogen use, Funct. Ecol. 13 (1999) 210-216.

[21] Maestre F.T., Cortina J., Bautista S., Bellot J., Vallejo V.H., Smallscale environmental heterogeneity and spatio-temporal dynamics of seedling establishment in a semi-arid degraded ecosystem, Ecosystems 6 (2003) 630-643.

[22] Marañón T., Villar, R., Quero J.L., Pérez-Ramos I.M., Análisis del crecimiento de plántulas de Quercus suber y Q. canariensis: experimentos de campo y de invernadero, Cuad. Soc. Esp. Cien. For. 20 (2004) 87-92.

[23] Marañón T., Zamora R., Villar R., Zavala M.A., Quero J.L., PérezRamos I.M., Mendoza I., Castro J., Regeneration of tree species and restoration under contrasted Mediterranean habitats: field and glasshouse experiments, Int. J. Ecol. Environ. Sci. 30 (in press).

[24] Meyer S.E., Carlson S.L., Achene mass variation in Ericameria nauseosus (Asteraceae) in relation to dispersal ability and seedling fitness, Funct. Ecol. 15 (2001) 274-281.

[25] Miao S., Acorn mass and seedling growth in Quercus rubra in response to elevated $\mathrm{CO}_{2}$, J. Veg. Sci. 6 (1995) 670-700.

[26] Navarro R., Fragueiro B., De Prado R., Díaz J.L., Guzmán R., Técnicas de conservación del suelo en forestaciones de terrenos agrícolas, in: Fernández P., González E.J., Martínez A., Navarro R. (Eds.), Mantenimiento y conservación del suelo en forestaciones agrarias, Asociación Española Agricultura de Conservación/Suelos Vivos-ETSI Agrónomos y de Montes, Universidad de Córdoba, Córdoba, España, 2004, pp. 41-73.

[27] Nicolás J.L., Domínguez S., Herrero N., Villar P., Plantación y siembra de Quercus ilex L.: efectos de la preparación del terreno y de la utilización de protectores en la supervivencia de plantas, Actas del II Congreso Forestal Español, vol. 3, 1997, pp. 449-454.

[28] Olsen S.R., Sommers L.E., Phosphorus, in: Page D.L. (Ed.), Methods of Soil Analysis. Chemical and Microbiological Properties, American Society of Agronomy and Soil Science Society of America, Madison, USA, 1982, pp. 403-430.

[29] Papatheodoru E.M., Stamou G.P., Nutrient attributes of tissues in relation to grazing in an evergreen sclerophyllous shrub (Quercus coccifera L.) dominating vegetation in Mediterranean-type ecosystems, J. Arid Environ. 59 (2004) 217-227.

[30] Paz H., Martínez-Ramos M., Seed mass and seedling performance within eight species of Psychotria (Rubiaceae), Ecology 84 (2003) 439-450.

[31] Porras C.J., Brun P., Copete J., Pérez R., Studies on holm oak regeneration in Sevilla mountains, Cuad. Soc. Esp. Cien. For. 17 (2004) $223-226$. 
[32] Querejeta J.I., Roldán A., Albadalejo J., Castillo V., The role of the mycorrhizae, site preparation, and organic amendment in the afforestation of a semi-arid Mediterranean site with Pinus halepensis, For. Sci. 44 (1998) 204-211.

[33] Retana J., Espelta J.M., Gracia M., Riba M., Seedling recruitment, in: Rodà F., Retana J., Gracia C., Bellot J. (Eds.), Ecology of Mediterranean evergreen oak forest, Springer-Verlag, Berlin, 1999, pp. 89-103.

[34] Rey Benayas J.M., Growth and mortality in Quercus ilex L. seedlings after irrigation and artificial shading in Mediterranean setaside agricultural lands, Ann. Sci. For. 55 (1998) 801-807.

[35] Reyes O., Casal M., Seed germination of Quercus robur, Q. pyrenaica and $Q$. ilex and the effects of smoke, heat, ash and charcoal, Ann. For. Sci. 63 (2006) 205-212.

[36] Rivas-Martínez S., Loidi J., Bioclimatology of the Iberian peninsula, Itinera Geobot. 13 (1999) 41-47.

[37] Seva J.P., Valdecantos A., Cortina J., Vallejo V.R., Different techniques for afforestation with Quercus ilex ssp. ballota (Desf.) Samp. in degraded lands (Comunidad Valenciana), Cuad. Soc. Esp. Cien. For. 17 (2004) 233-238.

[38] Smart A., Moser L.E., Switchgrass seedling development as affected by seed size, Agron. J. 91 (1999) 335-338.

[39] Terradas J., Holm oak and holm oak forest: an introduction, in: Rodà F., Retana J., Gracia C., Bellot J. (Eds.), Ecology of Mediterranean evergreen oak forest, Springer-Verlag, Berlín, 1999, pp. 3-14.

[40] Valdecantos A., Cortina J., Vallejo V.R., Respuesta de plantones de pino carasco y encina carrasca a la fertilización, Cuad. Soc. Esp. Cien. For. 10 (2000) 63-68.

[41] Valdecantos A., Cortina J., Fuentes D., Casanova G., Díaz-Beltrana J.M., Lavador F., Vallejo V.R., Use of biosolids for reforestation in the Region of Valencia (E Spain). First results of a pilot project, Bioprocessing Solid Waste Sludge 1 (2002) 1-6.
[42] Valdecantos A., Fuentes D., Cortina J., Utilización de biosólidos en la restauración forestal, in: Vallejo V.R. (Ed.), Avances en el estudio de la gestión del monte Mediterráneo, Fundación CEAM, Valencia, España, 2004, pp. 313-344.

[43] Valdecantos A., Cortina J., Vallejo V.R., Nutrient status and field performance of tree seedlings planted in Mediterranean degraded areas, Ann. For. Sci. 63 (2006) 249-256

[44] Valladares F., Martínez-Ferri E., Balaguer L., Pérez-Corona E., Manrique E., Low leaf-level response to light and nutrients in Mediterranean evergreen oaks: a conservative resource-use strategy? New Phytol. 148 (2000) 79-91.

[45] Valladares F., Pugnaire F.I., Tradeoffs between irradiance capture and avoidance in semi-arid environments assessed with a crown architecture model, Ann. Bot. 83 (1999) 459-469.

[46] Villar R., Ruíz-Robleto J., Quero J., Poorter H., Valladares F., Marañón T., Tasas de crecimiento en especies leñosas: aspectos funcionales e implicaciones ecológicas, in: Valladares F. (Ed.), Ecología del bosque mediterráneo en un mundo cambiante, Ministerio de Medio Ambiente, Madrid, España, 2004, pp. 191227.

[47] Villar-Salvador P., Planelles R., Enríquez E., Peñuelas J., Nursery cultivation regimes, plant functional attributes, and field performance relationships in the Mediterranean oak Quercus ilex L., For. Ecol. Manage. 196 (2004) 257-266.

[48] Williams D.E., A rapid manometric method for the determination of carbonate in soils, Soil Sci. Am. Proc. 13 (1948) 27-129.

[49] Zulueta J., Montoto J.L., Efectos de la temperatura y humedad en la germinación de bellotas de encina (Quercus ilex L.) y alcornoque (Quercus suber L.), Invest. Agrar. Sist. Recur. For. 1 (1992) 65-71. 